\title{
Development of Interactive Multimedia on Material Introduction the Wild Animal in Kindergarten: Research and Development in Early Childhood Teacher Education Program
}

\author{
Taruni Suningsih ${ }^{1}$, Yetty Rahelly ${ }^{2}$, and Rukiyah ${ }^{3}$ \\ ${ }^{1}$ Early Childhood Teacher Education Program, Universitas Sriwijaya, Palembang, Indonesia, \\ suningsih.taruni@gmail.com \\ ${ }^{2}$ Early Childhood Teacher Education Program, Universitas Sriwijaya, Palembang, Indonesia, \\ yettyrahelly@gmail.com \\ ${ }^{3}$ Early Childhood Teacher Education Program, Universitas Sriwijaya, Palembang, Indonesia, \\ rukiyah.unsri@gmail.com
}

\begin{abstract}
This manuscript is to developing interactive multimedia on material introduction the wild animal in kindergarten. This research used the development research method with the Allesi and Trollip model that consists of: planning phase, design phase, and development phase. Research subject used 25 students aged 5-6 years at Nusa Indah 1 Kindergarten in Palembang City. This research demonstrates that in this multimedia application there are four main menus, namely a menu about wild animal material, a learning video menu, a menu to count the number of wild animals, and a puzzle game menu. The results of validity test from experts obtained a score of 0,91 from the media expert and 075 from the material expert, so the average of validity test was stated in a very high category of validity, that means the developed interactive multimedia was declared valid and could be tested. The result of practically test of students obtained score of 0,95 which is stated in the category of very high level of practice, so that interactive multimedia is easily played by students.
\end{abstract}

Keywords: development; interactive multimedia; wild animal; kindergarten

\section{INTRODUCTION}

Early childhood education has a unique way of delivering the material, because in this age is a child at the age of play, so learning is given in this way. Combining elements of learning and play is a necessity in this level of education, because if one uses the method in its delivery, children are not only difficult to accept, but mistakes can occur early on about learning which in turn makes children reluctant to learn.

The choice of media is no less important than the choice of methods for early childhood education. In general, media is everything in the form of tools that facilitate educators in conveying information. Association of Education and Communication Technology (AECT) sets limits on the media as all forms and channels used to convey messages or information [1].

In particular, the media in early childhood education is a teacher's playing tool, because with that media the teacher invites children to learn by playing, unnoticed by the children, through the play process the teacher instills knowledge the habituation to children as education expert Jerome Brunner said: "Every material can be taught to every age group in ways that are suitable for its development. The key is play or play" [2]. So, in the world of Early Childhood Education, media selection takes into account the fun aspect, which is the presence of the game element in it.

Introducing the wild animals to children is not easy if it not accompanied by supporting media. In the theme of animals, children will learn about wild animals. Therefore, the media is needed that can arouse the imagination of children and children can interact with the media.

Introducing animal themes as a reference for development, from the existing themes, minimized by the existence of sub themes, then form this sub theme is integrated into seven aspects that must be developed in kindergarten and then the combination of aspects that must be developed with existing sub themes into a learning condition for meaning in children in kindergarten. To introduce animals to children, more specifically to the theme of animals, where in the animal theme, children will learn with the wild animal sub-theme.

One technology product can be used as an innovation in learning is to use computers. Computer-aided learning 
can improve emotional cognitive abilities, emotional linguistic, and literacy skills in pre-school children.

Interactive multimedia is one of the media that can be used in early childhood education. The use of interactive multimedia that uses a computer or laptop as a tool is expected to eliminate the tedious impression in the introduction of the natural environment that has been done by means of and uses media that can be said to be out of date, and interactive multimedia is also expected to help in the process introduction of the natural environment to kindergarten children. The more interactive the media presented to children, the more it will stimulate the nature of exploration and children's curiosity to continue learning.

Computer-based learning is also based on learning theories such as behavioristic theory, where this theory was pioneered by Thorndike (1913), Pavlov (1927), and Skinner (1974) who stated that learning is observable behavior due to external stimuli. Someone can be said to learn shown from the behavior that can be seen not from what is in the minds of students [3], further the development $f$ computer-based learning is based on cognitive psychological theory which states that learning includes the use of memory, motivation, thoughts, and reflection [4].

In particular, interactive multimedia also helps in the process of early childhood learning, interactive multimedia applications as learning media for early childhood on Android-based mobile phones are proven effective in helping children understand learning. Using technology can help young children to communicate, practice life skills and better understand concepts [5]. Interactive multimedia types of puzzle games are also very useful in children's learning because they have been proven to be able to increase learning interest and cognitive abilities of children.

This researcher, tried to provide a solution for educators in Nusa Indah 1 Kindergarten to introduce the types of wild animals, namely conducting research entitled Development of Interactive Multimedia on Material Introduction the Wild Animal in Kindergarten.

\section{THEORY}

\section{A. Interactive Multimedia}

Media is called an intermediary or delivery message from the sender to the recipient of the message [6]. Media are forms of communication both printed and audio-visual and their equipment. Media should be manipulated, can be seen, heard, and read. Media are communication channel tools such as films, television, diagrams, printed materials from computer and instructors.

Media are various types of components or learning resources in the learning environment that can stimulate learning to learn. The media are all or physical tools that can present messages and stimulate learners to learn. The essence of learning media as a place to convey messages or information from the source of the message is passed on the recipient [7]. The key words from this media are intermediaries or medium that the bridge a relationship between educators and students in the learning process. Some multimedia definitions according several experts include:
- Multimedia is various combinations of text, graphics, sound, animation, and video delivered using a computer or other electronic device [8].

- Multimedia refers to the integration or synchronization of media streams (any synchronized media streams), an example of multimedia is moving images that are in sync with sound (including television broadcasts and modern films) [9].

- Multimedia refers to various combinations of two or more media formats integrated into the form of information or program instructions [10].

Based on the opinions that have been raised above we can know that multimedia is basically a combination of existing media that is included in a multimedia, these media are audio, visual, animated, graphic, etc. in order to convey a message from the provider message to the recipient of the message. Whereas interactive multimedia is basically a combination of media devices of sound, images, animation, video, and interactive between the media used by students themselves is characterized by a controller on the media used so that students are free to use media. Interactive multimedia combines and synergizes all media consisting of text, graph, audio, animation, and video [11].

Interactive multimedia has its own criteria [12], that is:

- The first criterion is ease of navigation;

- The second criterion contains cognition content;

- The third criterion is information presentation;

- The fourth criterion is media integration;

- The fifth criterion is artistic and aesthetic; and

- The last evaluation criterion is the overall function.

B. Characteristic of Multimedia Interactive

Media can be divided into two types, based on their use and development [13], namely:

- Human-based media, that is in their application to make humans as a tool to convey messages;

- Print-based media, namely media that are applied using print media such as books, modules, etc;

- Visual-based media, that change visual material such as images, etc;

- Audio Visual media, that uses visual media such as images and sound in its media components;

- Computer-based media, which of course, uses computers, and the last;

- The use of libraries as learning media, which of course, uses everything in the library to be used as media.

\section{RESEARCH METHOD}

This research aims to produce a product. To achieve these objectives, the method used in this study is the Development Research Method, a research procedure used to produce educational products and test their effectiveness [14]. This study refers to the development model of Alessi and Trollip.

The development model used in this study is the development model of Alessi and Trollip which are oriented to non-printed products on teaching materials. The use of this development model because this model is 
devoted to developing learning multimedia. This development model consists of three stages, namely the planning stage, the design phase, the development stage [15].

\section{RESULT}

The results of this study indicate that improving student learning outcomes in aspects of cognitive development, especially in the material to recognize animals that are not in the child's environment affect educators displaying interactive multimedia to recognize animals that are not in the child's environment easily and more quickly understood by students. Interactive multimedia that contains material about recognizing animals that are not present in the child's environment (tigers, elephants, snakes, lions, giraffes, zebras, crocodiles, rhinos, penguins, and sharks) based on puzzle games that researchers have developed give the impression of fun, can help the learning process and know animals that are not in the student environment.

Children will remember the learning material more if it is supported by visual aids or visualization and animation giving a pleasant impression in the learning process [16]. Benefits of learning media in the learning process will attract more attention of students so that it can foster learning motivation for students [17]. High motivation to students will bring students more enthusiasm for learning. This century is even important to include the use of ICT in the learning environment, therefore the ability of an educator to help students, depend on the mastery of knowledge structures in the realm taught. Early Childhood Educators can build on this enthusiasm and provide a rich context that builds ICT as an integral part of the learning program so that educators remain a relevant and contemporary part of society.

Students learning outcomes increase in aspects of cognitive development, especially in the material to recognize animals that are not in the child's environment affect educators displaying interactive multimedia to recognize animals that are not in the child's environment affect educators displaying interactive multimedia to recognize animals that are not in the child's environment easily and more quickly understood by students. Interactive multimedia that contains material about recognizing animals that are not present in the child's environment (tigers, elephants, snakes, lions, giraffes, zebras, crocodiles, rhinos, penguins, and sharks) based on puzzle games that researchers have developed give the impression of fun, can help the learning process and know animals that are not in the student environment.

Researchers found that the use of interactive multimedia in learning in kindergarten contributes to the improvement of aspects of cognitive development, especially about the material to recognize animals that do not exist in the environment of children there is a relationship between the used of interactive multimedia based teaching materials with the activeness of students in the learning process. The percentage of activeness of students at the first and second meetings respectively by $79 \%$ and $94.5 \%$ included in the category of good and very good. Test the effectiveness of student learning activities at the field test stage included in the active category because interactive multimedia is very effective in increasing learning activities.

With these findings it is hoped that it can motivate educators, especially kindergarten educators, in implementing learning in kindergarten by displaying learning media that are not only sourced from textbooks and posters but can display learning media in the form of text, images, and sounds to make it more interesting and students are more motivated to learn.

The research developed interactive multimedia on aspects of cognitive development. This research is the same as the research that interactive multimedia researchers developed for cognitive aspects of children with material to recognize animals that do not exist in the child's environment. This interactive multimedia developed also shows the activeness of students in learning and makes a teaching approach used in the learning process so that learning becomes active, innovative, creative, effective, and fun. Interactive meanings as a learning process for students to control the learning environment. In this context the learning environment in question is learning by using a computer. Interactive classification within the scope of learning multimedia lies not I the hardware system, but rather refers to the characteristics of students in responding to the stimulus delivered by a computer monitor screen.

Interactive multimedia based learning is one from ICT utilization that needs to be improved in the learning process due to be improved in the learning process due to application with multimedia interactive with animation, video, text, and sound can make students more active, innovative, and more fun. The development of interactive multimedia can be an alternative in helping young children understand material that does not exist in the environment of the child and become an educational tool for educators and parents. The final result of this research is product development in the form of interactive multimedia based on puzzle games on basic competencies in knowing the natural environment (knowing animals that are not in the environment of children).

Based on the description above it can be concluded that the developed learning application is considered feasible to use both in terms of content and media. Aside from passing the assessment stage by experts, this learning application also passes the revision stage for improvement based on suggestions from media experts, material experts, and learning design experts. After the revised interactive multimedia product is carried out, besides that this interactive multimedia teaching material has been categorized practically for use by students based in a needs analysis done previously. Besides that students give a good response during the learning process by using this interactive multimedia teaching material. During the learning process looks active and enthusiastic in learning. The advantage of using computer aided teaching materials in the learning process can improve learning outcomes.

\section{CONCLUSION}

Based on the results of research conducted on interactive multimedia puzzle-based games on basic competencies to know the natural environment (material to recognize animals that do not exist in the environment of 
children) aspects of cognitive development can be concluded as follows:

- The process of developing interactive multimedia to produce media learning applications to recognize animals that do not exist in a child's environment is done through three stages, namely: the planning stage; the learning design stage; and the development stage of the learning application. In this application there are five main menus, which are pictures, numbers 1-10 that are accompanied by animated pictures of animals, then material about 10 types of animals that are not in the child's environment, then a video containing about the lives of wild animals that do not exist in the child's environment and the last is a puzzle game as an introduction to animals that are not in the child's environment to measure students' ability to use interactive multimedia products.

- Alpha test results from experts in addition to the form of comments and suggestions used as a reference to revise the interactive multimedia product that was developed. Quantitative assessment of interactive multimedia that is developed that is obtained through the average results of the assessment of experts obtained a number of 0.91 from media experts, 1 from material experts and 0.75 from learning design experts, with a very high category of validity, so interactive multimedia is developed otherwise valid and can be tested according to advice.

- Beta test results are obtained from the ministry and suggestions from respondents regarding interactive multimedia from students. In the beta test phase with six students. The mean score of respondent quantitative evaluation of interactive multimedia that was developed was 0.95 and was categorized as very high practically for use in research.

\section{REFERENCES}

[1] A. Arsyad, Media Pembelajaran, Jakarta: PT Raja Grafindo Persada, 2014, p.13.

[2] M.Y. Bustomi, Melejitkan Potensi dan Kecerdasan Anak Usia Dini, Jakarta: Citra Publishing, 2012, p. 74.

[3] M. Ally, Foundation of Educational Theory for Online Learning, Canada: Athabasca University, 2004, p.7.

[4] Rusman, Media Pembelajaran Berbasis Komputer, Bandung: Alfabeta, 2013, p.112.

[5] J, Keengwe \& G, Onchh-Wari. Technology Interaction Profesional Development Model for Practicing Teacher, Technology and Eary Childhood Education Journal, 2009, p. 209.

[6] A. Arsyad, Media Pembelajaran, Jakarta: PT Raja Grafindo Persada, 2014, p.3.

[7] Rusman, Media Pembelajaran Berbasis Komputer, Bandung: Alfabeta, 2013, p.161.

[8] T, Vaughan. Multimedia: Making it Work Second Edition, USA: McGraw-Hill, 1994.

[9] T.D. Green \& A. Brown, Multimedia Project in The Classroom, USA: Corwin Press Inc, 2002.

[10] D. Heinich, Molenda \& E, Smaldino. Instructional Technology and Media for Learning, New Jersey: Pearson Merril Prentice Hall, 2002.

[11] T.D. Green \& A. Brown, Multimedia Project in The Classroom, USA: Corwin Press Inc, 2002.

[12] Thorn, Points to Consider When Evaluating Interactive Multimedia The Internet TESL, Journal 2, 2006, p. 4

[13] A. Arsyad, Media Pembelajaran, Jakarta: PT Raja Grafindo Persada, 2014, p.80.

[14] Sugiyono, Metode Penelitian Kuantitatif, Kualitatif, dan R\&D, Bandung: Alfabeta, 2008.

[15] S. M. Alessi \& S. P. Trollip, Multimedia for Learning: Methods and Development. Boston: Allyn \& Bacon, 2001.

[16] Suparmi, Metode Pembelajaran Membaca Doa Berbasis Multimedia untuk Anak Usia Dini, IJSEIndonesia Journal on Software Engineering 2 (1), 2016 , p. 57.

[17] N. Sudjana \& A. Rivai, Media Pengajaran, Bandung: Sinar Baru Algesindo, 2002. 